
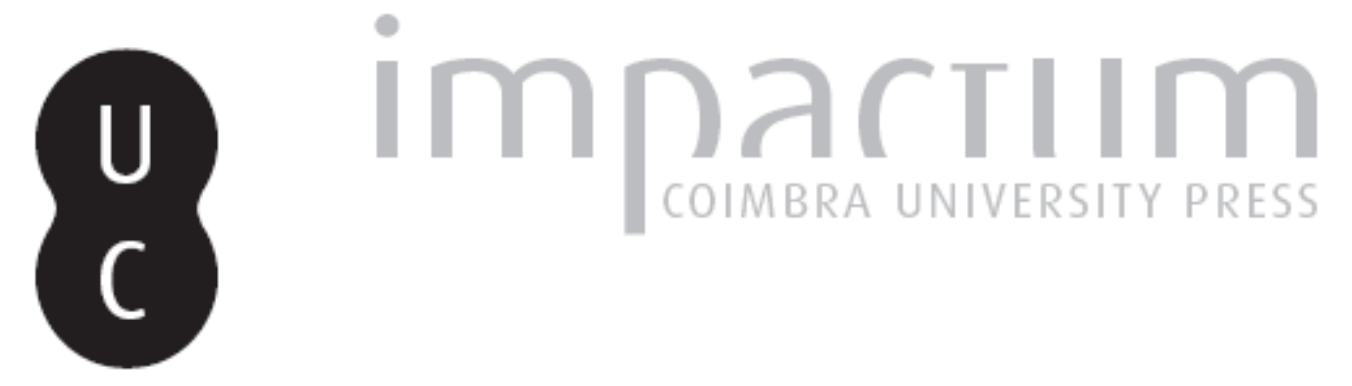

\title{
Response to Christopher Rowe
}

Autor(es): Kahn, Charles $\mathrm{H}$.

Publicado por: Imprensa da Universidade de Coimbra

URL persistente:

URI:http://hdl.handle.net/10316.2/42271

DOI:

DOl:https://doi.org/10.14195/2183-4105_2_5

Accessed : $\quad$ 26-Apr-2023 11:33:12

A navegação consulta e descarregamento dos títulos inseridos nas Bibliotecas Digitais UC Digitalis, UC Pombalina e UC Impactum, pressupõem a aceitação plena e sem reservas dos Termos e Condições de Uso destas Bibliotecas Digitais, disponíveis em https://digitalis.uc.pt/pt-pt/termos.

Conforme exposto nos referidos Termos e Condições de Uso, o descarregamento de títulos de acesso restrito requer uma licença válida de autorização devendo o utilizador aceder ao(s) documento(s) a partir de um endereço de IP da instituição detentora da supramencionada licença.

Ao utilizador é apenas permitido o descarregamento para uso pessoal, pelo que o emprego do(s) título(s) descarregado(s) para outro fim, designadamente comercial, carece de autorização do respetivo autor ou editor da obra.

Na medida em que todas as obras da UC Digitalis se encontram protegidas pelo Código do Direito de Autor e Direitos Conexos e demais legislação aplicável, toda a cópia, parcial ou total, deste documento, nos casos em que é legalmente admitida, deverá conter ou fazer-se acompanhar por este aviso.

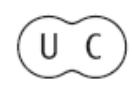




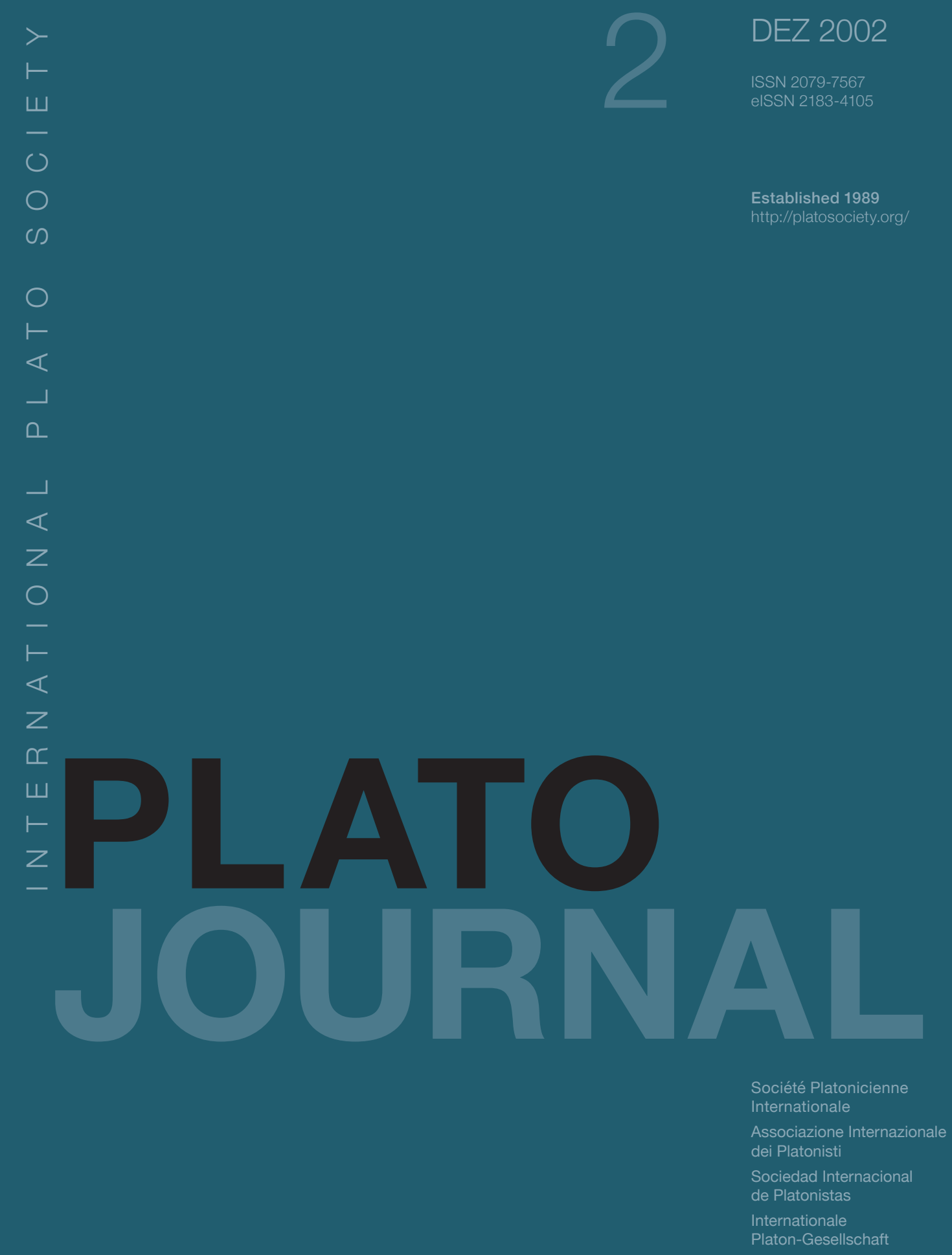




\title{
Response to Christopher Rowe
}

\author{
KAHN, Charles, H., in 2. Plato 2 (2002),
}

[En ligne], January 2002

I want to thank Christopher Rowe for his thoughtful criticism of my Plato book, and for giving me the opportunity to reflect on this book some five years after it was sent to the press.

It is clearer to me now that the book represents two different projects, one negative and one positive. The negative project is basically historical. I set out to refute two views that I regard as obstacles to an insightful reading of the dialogues. One view that I want to get rid of refers to the historical Socrates and one refers to stages in Plato's philosophical development. The first obstacle to be removed is the assumption that the earlier dialogues represent the philosophy of the historical Socrates. My thought was that in order to do justice to Plato's genius as a philosophical writer, one must first free him from the shadow, or rather the ghost, of the historical Socrates. Once we have recognized the fictional element in all the Socratic literature, we can no longer hope to extract an historical kernel from Plato's representation. (Of course we must believe that Plato's depiction of Socrates' personality is not entirely unfaithful to his own memory of the man. But when it is a question of philosophical content, Plato's attitude is no longer that of an historian.) On the other hand, anyone who has worked with Aristotle's treatment of the Presocratics, or with some of his criticisms of Plato, will agree with Christopher Rowe that Aristotle 'is generally a poor historian (§16) of philosophy', that is, he is not a sympathetic interpreter of other philosophers' views. And in the case of Socrates, the only documentation Aristotle had to rely on was his own reading of the Socratic literature. Hence if we agree with Momigliano, Andreas Patzer and others that the Socratic dialogue is not a historical genre, we must resign ourselves to knowing very little about the philosophical views of the historical Socrates.

The second obstacle to be removed is a certain version of the developmental approach, the assumption that, from dialogue to dialogue, we can see Plato changing his mind. I submit that it is not so easy to read Plato's mind. To get from the text of the dialogues to any view that we can ascribe to Plato requires a hermeneutical hypothesis, an assumption about why Plato writes dialogues in the first place, and what his attitude is towards the various doctrines and theses presented in the text. The developmental hypothesis requires one set of assumptions, my moderate unitarian hypothesis implies a different set. In particular, I assume that dialogues are quite different from treatises, notebooks or journal articles, and that Plato does not write to clear his mind, set down his momentary thoughts, or experiment with ideas he has not yet thought through. The dialogues are art-works, the finished products of a careful writer. They give the impression that Plato always knew where he wanted to go, that he writes to make a certain impact on the readers, to attract them into philosophy by debating issues that they would find important and by challenging their customary assumptions. In the long run, he also used the dialogue form to introduce the reader into his own, specifically Platonic, world-view. The Phaedo and the Republic seem to me the dialogues in which Plato is most explicit in presenting his own position (although with all sorts of qualifications and incompleteness). I think we can recognize Plato's relative openness in these two dialogues not only from the earnestness with which Socrates presents his views but above all from the fact that we meet essentially the same world-view (though of course not exactly the same doctrines) in the Timaeus, the Seventh Letter, the digression in the Theaetetus, and many passages in the later works. So my unitarian hypothesis is a proposal to read all the dialogues — and in particular all the early ones - as the work of an author whose world-view is defined by the Phaedo and Republic. But Plato did not believe that any doctrine or formula could successfully communicate this view to a reader in any direct way, so all of his most constructive statements are provisional, incomplete and subject to criticism and correction. Instead of fixed doctrines we have large and flexible schemata, like Recollection and the noetic vision of the Forms, or like Dialectic which is redefined in every dialogue. The advantage of the dialogue form is that it is irremediably perspectival - a discussion with particular interlocutors at a particular moment, with some things taken for granted and other things argued for. That is what I mean by moderate unitarianism: there is a single Platonic world-view, but no single expression of it. Even if there is a god's eye point of view, that point of view is not available to humans. Hence no particular formulation can be the last word - not even the Unwritten Dogmata of which we have heard rumors.

Just as there are dialogues with more explicit statements of the Platonic vision and others with less, or with criticisms (as in the Parmenides) or alternative proposals (as in the Theaetetus), so there are dialogues with barely a hint of positive philosophical theory. Such are the dialogues we call Socratic. The most economical assumption is that, since their author is the same, his philosophical views are the same as when he wrote the Phaedo and the Republic. Here Christopher Rowe seems to disagree, and to support a moderate developmentalism, at least with regard to moral psychology. (By 'developmentalism' I mean the view that some dialogues reflect a Platonic philosophy that is incompatible with that of the Phaedo and Republic.) The question is: which is the more fruitful hermeneutical hypothesis: unity or development? The proof of the pudding is in the eating. Which hypothesis provides the 
basis for a more faithful and insightful reading of the Laches and the Charmides, the Protagoras and theSymposium? That is the topic for a future debate.

On one point I would like to correct an impression given in my book. There I tended to link my unitarian thesis to claims about Plato's literary strategy in 'proleptic' presentation in one dialogue of ideas that would be fully developed only in another, later work. I do not mean to withdraw my suggestions about proleptic composition, but only to point out that the unitarian thesis does not depend upon such claims. The unitarian thesis is a hermeneutical hypothesis formulated from our point of view as interpreters today, with the whole corpus before us. My hypothesis is to interpret all the dialogues from the philosophical position defined by the Phaedo and Republic, or at least to read them all as compatible with that position. But this proposal implies nothing about the chronology of composition. On the other hand, the proleptic view presupposes some assumptions about relative chronology and about authorial intent in a more specific way. For example, the unitarian thesis requires us to understand theMeno and the Phaedo as expressions of the same general theory of Recollection, but it says nothing about the order of composition, or about the author's literary motive for presenting Recollection in the Meno without mentioning the Forms as objects to be recollected. The proleptic approach, on the other hand, will explain why the Meno is silent on the subject of Forms, and also why the Phaedo contains a quasireference back to the Meno when Recollection is introduced (at Phaedo 73a-b). My theory of proleptic composition is stronger than the unitarian hypothesis: it explains more, but only by making more assumptions. And it is a more literary-historical theory, making claims about chronology and about the author's literary strategy. The unitarian hypothesis is more strictly hermeneutical and philosophical: it is about how we are to construe the philosophical content of the dialogues.

Perhaps I should say something to clarify my view about what is called Socratic intellectualism. Christopher Rowe suggests that like Gregory Vlastos, I regard Socratic intellectualism as a psychologically implausible theory. My position is in fact more complex than Rowe brings out, and I would draw a rather sharp distinction between intellectualism or rationalism in general and the denial of akrasia in particular. I want here to develop briefly my discussion of the topics in the book in response to Rowe's critical comments.

The evidence of 'Socratic' intellectualism is of two kinds: (1) passages in the dialogues where virtue is identified with knowledge, or defined as a kind of knowledge, and (2) the denial of akrasia. Evidence for (2) is most explicit in the Protagoras. In other dialogues before the Republic, the possibility of akrasia is never mentioned, but it is relevant to some passages in the Gorgias and the Meno.

The identification of virtue with knowledge implies an apparent neglect of the emotional factors in moral character and in decisions to act. This neglect is what Vlastos took to be a psychological error committed by the historical Socrates. My concern, however, is only with the Socrates of Plato's dialogues. I also see one strand of Socrates' thought as more fully articulated than the other strand. I want to suggest a two-part answer to the question why Plato was willing to have Socrates affirm, not only the necessity, but also the sufficiency of wisdom for moral virtue.

The Gorgias presents, and Aristotle in the Ethics develops, what I call the classical theory of rational action. This theory assumes that all actions are done for the sake of the good (or for good things), present in all human beings as a fundamental principle of their psyche [1]. By 'good' here is meant both (a) good for the agent, beneficial, and also (b) good absolutely, that is, good for any agent as the final goal of all his actions. (It is the task of moral theory to show how these two conceptions of good coincide.) The classical view is most clearly expressed by Aristotle in his claim that we desire something because we judge it good, we do not judge it good because we desire it. This notion of things done 'for the sake of (something) good' amounts to an implicit definition of rational action. Thus, for Plato in the Gorgias, an action counts as rational, as an expression of boulesthai, only if the agent has an end in view that he perceives as good, and if he deliberately pursues that action as a means to achieving this end.

Thus all rational actions are done for the sake of a perceived good. They are done because the agent judges the action or its consequences to be good. But, of course, the agent may be mistaken. That is why wisdom is necessary for virtue. But why is it sufficient? Plato's implicit answer, I take it, is because the desire for the good is universal in human beings. So anyone wise enough to know what is good will necessarily desire it, and act accordingly. This is Plato's interpretation of the Socratic paradox: anyone who acts badly, or for the sake of a bad outcome, is not doing what he really wants (since what he wants is the good). So his action in this case is involuntary.

This classical theory of action, outlined in the Gorgias (in Socrates' discussion with Polus) and implied in the Meno and elsewhere, does not entirely ignore the emotions, but it takes account only of the rational desire for what is judged good. But what about nonrational desire such as sexual passion, fear or anger? And what about weakness of the will: acting contrary to one's judgment of what is good, because of the force of these other motivating principles?

These are questions that the Platonic Socrates generally ignores (before the Republic, when for the first time he sketches a general theory of human motivation). The earlier dialogues are concerned with the fundamental need for moral wisdom rather than with its limitations. Only occasionally, as in the confrontation with Callicles in the Gorgias, is there a serious discussion of non-rational desires, and even then, not in the context of a general theory of human motivation to a problem of rational choice. Before theRepublic, only in the Protagoras does Socrates raise the question of the limits of rational control over human action, and here he 
gives the highly paradoxical answer that there are none: what is generally thought to be the distorting effect of the passions is really a mistake in calculation. (Other passages that may be taken to imply or allude to a denial of akrasia include Gorgias 460b and Meno 77e-78a.)

Why does the Protagoras take such a hard line, reducing the power of the passions to a mistake in measurement, and reducing human motivation to the pursuit of pleasure and the avoidance of pain? Well, first of all it makes for a very elegant theory. And furthermore, the whole dialogue is not set up in such a way as to prepare for the first attempt in history to offer a realistic theory of human psychology, of the kind that Plato will in fact offer in the Republic. Consider the dramatic setting, the huge build-up of Protagoras as the wisest man in Greece and the highly competitive position of Socrates as the young challenger in this very public venue, the challenger whose skill in dialectical manipulation will bring down the champion in defeat. Just as Socrates outdoes Protagoras in creative misinterpretation of Simonides' poem, so he tops Protagoras' very sensible account of moral education in the Great Speech by a brilliantly perverse account of akrasia and cowardice as miscalculation. The Protagoras is not the place to look for Plato's own theory of moral psychology - just as it is not the place to find Socrates' conception of virtue as the health of the soul either.

Still, we are left with this question in the Protagoras: why the concern with akrasia?

First of all, there are specific reasons in the context of the Protagoras: it is necessary for Socrates to eliminate akrasia in order to win his argument against Protagoras and explain cowardice as an error in measurement. At a more general level, akrasia poses a problem for the Socratic paradox that no one is voluntarily bad or unjust. I take it that the classical theory of action was designed to support the paradox: since everyone desires the good and everyone acts for the sake of the good, bad action must be due to ignorance of the good and be in this respect involuntary. But suppose one knows what is good but nevertheless does what is bad because of moral weakness, because one's better judgment is overcome by fear or by lust? In the end, Plato (unlike Aristotle) will count akratic actions as involuntary, just like actions due to ignorance, since they do not aim at the good. In the Protagoras he has taken the more direct course of simply identifying akratic actions with acts done in ignorance of the good (i.e. by a mistake about what is better).

I want to suggest that, although in the long run Plato is not really interested in the distinction between akrasia and vice, he perceptive enough to realize that akratic acts are going to be a stumbling-block for his claim that all actions are done for the sake of some good, the foundation of the classical theory. In the Republic he will develop the broader motivational theory that takes non-rational desires into account. In the Protagoras, on the other hand, he salvages the Socratic paradox and the conception of virtue as wisdom by simply denying the reality of moral weakness and reinterpreting the appearance of weakness in intellectual terms. Hence in this dialogue Plato is able to present rational choice theory as a general theory of human action.

\section{CHARLES H. KAHN}

University of Pennsylvania

USA

Footnotes

[1] All actions are done for the sake of the good in Gorgias and Republic; boulêsis as rational desire for good in Aristotle. 